\title{
A CONSTRUÇÃO DE CENÁRIOS SIMULADOS COM SITUAÇÕES DE EMERGÊNCIAS PARA OS TREINAMENTOS DE PROFESSORES E FUNCIONÁRIOS NO AMBIENTE ESCOLAR
}

\author{
Estelamares Silva dos Santos Moraes \\ Enfermeira da Divisão de Educação Infantil e Complementar da UNICAMP \\ esmoraes@unicamp.br
}

OBJETIVO: Relatar a experiência da utilização de cenários simulados para o treinamento de professores e funcionários no ambiente escolar. MÉTODOS: Estudo descritivo e exploratório, realizado em uma escola de educação infantil no município de Campinas que atende cerca de 800 crianças de zero a seis anos. Foram criados três cenários de simulação de emergências utilizando atores, maquiagens para ferimentos e situações cotidianas de possíveis emergências que possam a vir ocorrer no ambiente escolar como: ferimentos, fraturas, engasgo, convulsões e parada cardiorrespiratória. O cenário 1 referiase a uma criança de aproximadamente quatro anos, brincando no pátio da escola, quando então ela tropeça e cai, fazendo uma fratura exposta no braço esquerdo, não bate a cabeça e fica sentada no chão gritando e chorando muito. O cenário 2 referia-se a um aluno, que está com várias blusas, relatando frio, seguindo a caminho da diretoria dizendo que está com muita febre e que vai pedir uma medicação para diretora, quando de repente ele cai e começa a convulsionar. E o cenário 3 são dois alunos brincando no refeitório quando de repente um deles engasga, inicialmente com tosse e após não consegue mais tossir, o colega tenta bater nas costas, sem sucesso para desengasgar e a vítima desmaia evoluindo para uma parada cardiorrespiratória. Os atores dos cenários foram os bolsistas do projeto de extensão universitária "Primeiros Socorros na Escola" e alunos do curso de graduação em enfermagem. Cada cena durou em média 10 minutos. RESULTADOS: Participaram do treinamento com duração de duas horas, 150 professores e funcionários, dois participantes voluntariavamse para as simulações de atendimentos em cada cenário, com duração aproximada de cinco minutos. Ao final do cenário todos os participantes discutiram as situações e foram ensinados a proceder corretamente nestas situações de emergências. CONCLUSÕES: A utilização de simulação realística com atores para treinamentos em emergências contribui positivamente para 0 
ensino de conhecimentos e habilidades nos atendimentos de emergências para leigos.

Palavras-chave: Escola. Treinamento de professores. Alunos. 